\title{
Unexplained bone pain and sexual addiction
}

\author{
Jean-Charles Crépin, Mathieu Blot, Marielle Buisson, Lionel Piroth
}

Infectious Diseases Department, CHU, Dijon, France

\section{Correspondence to}

Pr Lionel Piroth,

lionel.piroth@chu-dijon.fr

Accepted 10 May 2018

\section{DESCRIPTION}

A 61-year-old single man with three children and a history of epididymo-orchitis and urethral stenosis 2 years earlier had suffered from bone pain for 3 months. The pain was disabling and affected the legs, pelvis and forearms. He had neither fever nor asthenia but had lost $8 \mathrm{~kg}$. He was treated with paracetamol and tramadol with poor improvement. Then a discrete maculopapular rash of the trunk appeared, initially suggesting a drug reaction. At admission to hospital 6 months after the onset of the symptoms, the patient reported multiple bisexual relationships for about 2 years. There were slight painful indurations of the tibial crests and slightly infiltrated coppery palmoplantar papules with a thin squamous rim (figure 1), without any other clinical abnormality.

X-ray and CT scan revealed cortical osteolysis associated with periosteal reactions in the two tibias, the sternal manubrium, the 7 th and 11th left ribs and both radius and ulnas (figures 2 and 3). Bone marrow puncture and protein electrophoresis were normal. Syphilis serology was positive with Treponema Pallidum Hemagglutinations Assay (TPHA) at 1/20 480 and Venereal Disease Research Laboratory (VDRL) at 1/16. Hepatitis and HIV serology were negative. Cerebrospinal fluid examination was normal. Penicillin-G treatment $4 \mathrm{MIUx6/day} \mathrm{was}$ initiated for 15 days, and bone pain resolved within

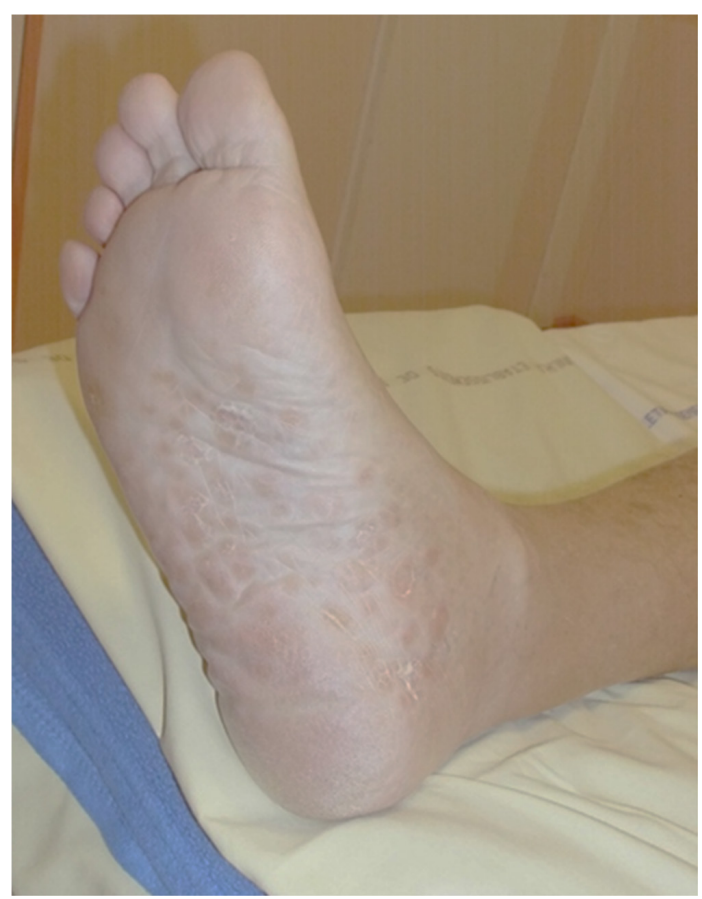

Figure 1 Plantar papules with a thin squamous rim, 'Biett's' collarette.

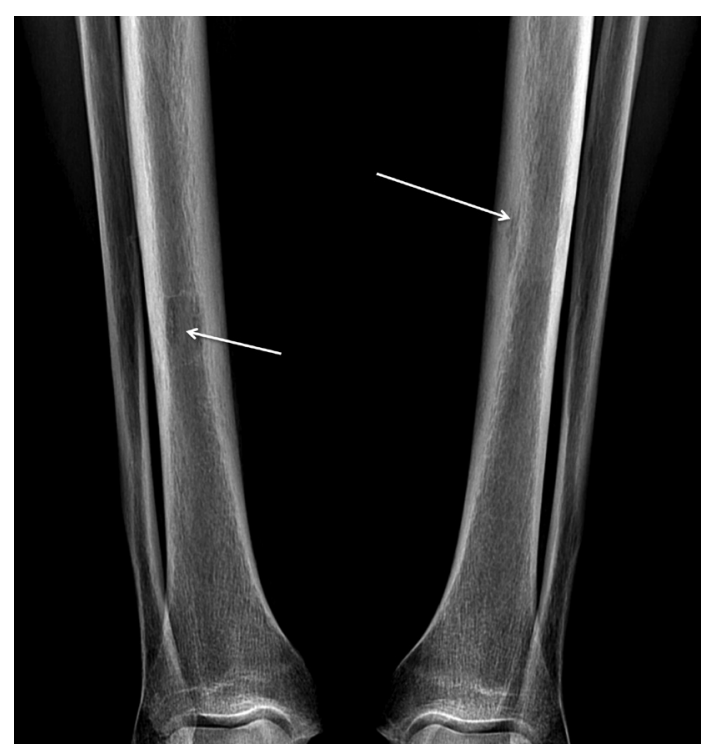

Figure 2 X-ray of both tibias and fibulas; white arrows indicate areas of cortical osteolysis.

7 days. Three months later, bone CT scan showed an almost total resolution of the bone lesions.

Syphilis is a sexually transmitted disease with a wide variety of symptoms. Its incidence has been rising since 2000 in many countries, as in the USA (from 2.1 to $8.7 / 100000$ between 2000 and 2016). Syphilis mainly affects men who have sex with men, often HIV infected $\left(47 \%{ }^{1}\right)$. Secondary syphilis may concern many organs, but very rarely the bone, with only 37 cases reported in 49 years.
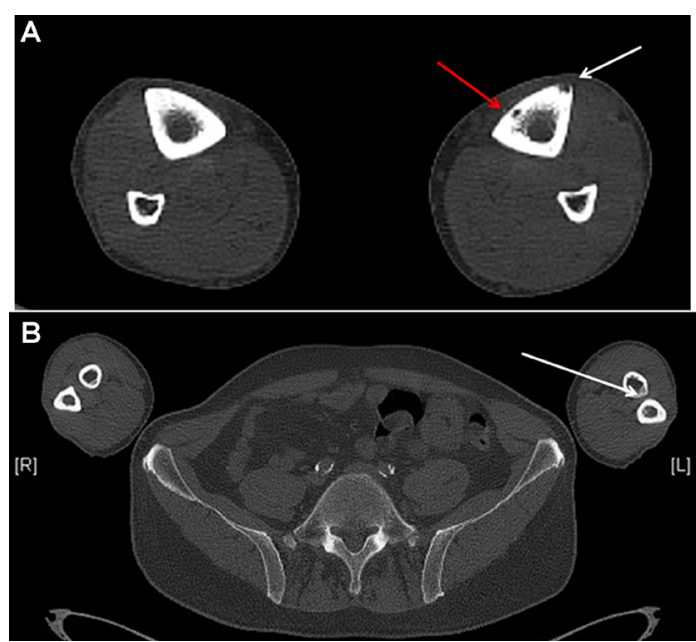

Figure 3 (A) Axial CT image of tibia and fibula: the red arrow indicates the periostitis reaction; the white arrow indicates area of cortical osteolysis. (B) Axial CT image: white arrow indicates area of cortical osteolysis of left radius. 
The most frequently affected bones were long bones of the limbs (60\%), the skull (57\%) and ribs (14\%). ${ }^{2}$ To observe spirochetes on bone biopsy is erratic. Indeed, only five cases were associated with the presence of a micro-organism in the biopsy, never by using the same technique ${ }^{2}$ : either darkfield microscope, silver or immunoperoxidase staining or PCR. Histopathology examination usually finds plasmacytic infiltration.

X-rays typically show multifocal bone destruction and sometimes periostitis. Differential radiological diagnoses include multiple myeloma, cancer, bone metastatic lesions, amyloidosis, sarcoidosis, tuberculosis and Paget's disease. ${ }^{3}$ Yaws has a similar radiological aspect of polyosteoperiostitis but localised rather in the feet and hands and usually more severe than in syphilis.

This case was treated as tertiary syphilis, because the bone involvement was severe. Moreover, treatment data on the

\section{Learning points}

- Early syphilis, as the great imitator, can induce multifocal bone destruction and periostitis causing bone pain.

- Unexplained bone pain may discuss syphilis in patients with at-risk sexual intercourses. efficacy of intramuscular penicillin $\mathrm{G}$ for syphilitic bone lesions are limited. ${ }^{3}$

In conclusion, bone syphilis is relatively easy to diagnose with serological tests and also easy to treat with penicillin G. The main challenge is now to evocate such a diagnosis, in particular in front of unexplained bone pain in patients with at-risk sexual intercourses.

Contributors All authors managed the case and reviewed the manuscript. J-CC and LP wrote the manuscript.

Funding The authors have not declared a specific grant for this research from any funding agency in the public, commercial or not-for-profit sectors.

Competing interests None declared.

Patient consent Obtained.

Provenance and peer review Not commissioned; externally peer reviewed.

(c) BMJ Publishing Group Ltd (unless otherwise stated in the text of the article) 2018. All rights reserved. No commercial use is permitted unless otherwise expressly granted.

\section{REFERENCES}

1 Kidd S, Torrone E, Su J, et al. Reported primary and secondary syphilis cases in the United States: implications for HIV Infection. Sex Transm Dis. In Press. 2018.

2 Park KH, Lee MS, Hong IK, et al. Bone involvement in secondary syphilis: a case report and systematic review of the literature. Sex Transm Dis 2014;41:532-7.

3 Smith JE, Adair LB, Press HC. Destructive lesions of bone: X-ray differential diagnosis. J Natl Med Assoc 1976;68:331-3.

Copyright 2018 BMJ Publishing Group. All rights reserved. For permission to reuse any of this content visit http://group.bmj.com/group/rights-licensing/permissions.

BMJ Case Report Fellows may re-use this article for personal use and teaching without any further permission.

Become a Fellow of BMJ Case Reports today and you can:

- Submit as many cases as you like

- Enjoy fast sympathetic peer review and rapid publication of accepted articles

- Access all the published articles

Re-use any of the published material for personal use and teaching without further permission

For information on Institutional Fellowships contact consortiasales@bmjgroup.com

Visit casereports.bmj.com for more articles like this and to become a Fellow 